\title{
BUSINESS DEMOGRAPHY DYNAMICS IN PORTUGAL: A NON-PARAMETRIC SURVIVAL ANALYSIS
}

\author{
Alcina NUNES \\ Superior de Tecnologia e Gestão do Instituto Politécnico de Bragança \\ Campus de Sta Apolónia, Apartado 1134, 5301-857 Bragança, Portugal \\ alcina@ipb.pt \\ Elsa SARMENTO \\ Departamento de Economia e Gestão da Universidade de Aveiro \\ Campus Universitário de Santiago, 3810-193 Aveiro, Portugal \\ esarmento@egi.ua.pt
}

\begin{abstract}
:
We address the post-entry performance of new Portuguese firms by investigating the structural characteristics of the hazard and survival functions, using non-parametric survival analysis. In order to approach prevalence of some stylized facts and determinants of new firm survival, we produced a new entrepreneurship database, using the administrative data of Quadros de Pessoal, following the Eurostat/OECD's internationally comparable business demography methodology. This allowed the computation of a comprehensive array of entrepreneurship indicators on employer enterprise and survival dynamics in Portugal, over a period of 18 years, disaggregated in dimensions such as sectors, regions and size classes.
\end{abstract}

Keywords: Entrepreneurship, Business Demography, Business Survival, Performance Determinants, Micro-data.

JEL codes: M13, M20 


\section{Introduction}

Most empirical studies on regional variations in entry and exit rates at the international level are either based on survey data like the Global Enterpreneurship Monitor (Acs et al., 2008), business data (Hoffman and Junge, 2006), business registration data (Klapper et al., 2008; Klapper et al., 2009) or a mix of the previous (Baterlsman et al., 2005; Baterlsman et al., 2005b; Scarpetta et al., 2002; Ahn, 2001). Moreover, most only take into account the manufacturing sector. There is scarce evidence of studies on entrepreneurial activity that encompass simultaneously all sectors, regions and countries. Portugal is somehow an exception, where extensive research has been done in firm dynamics using mostly Quadros de Pessoal (Mata and Portugal, 1994; Mata et al., 1995; Mata, 1993; Mata and Machado, 1996; Görg et al., 2000; Baptista et al., 2008; Cabral, 2007; Cabral and Mata, 2003; Baptista and Carias, 2007; Baptista and Mendonça, 2007).

The main contribution of our work is the application of a recent internationally comparable methodology for entrepreneurship and the usage of this analytical arsenal, to provide a multidimensional overview of firm and survival dynamics in Portugal. Over a period of eighteen years, firm and survival disaggregation is provided, in dimensions such as sectors, regions and size class, while guaranteeing international comparability with other datasets, namely with those that consider employer enterprises, such those recently developed by the Eurostat/OECD's for the Entrepreneurship Indicators Programme (EIP). To our knowledge, there is not yet a study on firm dynamics or survival that encompasses such a long run perspective, with such a level of detailed disaggregation across so many dimensions.

Following a brief description of the methodology and of the dataset, we describe the performance dynamics of firm entry and exit and survival in Portugal across seven regions, four broad sectors and six size classes. Section 4 is dedicated to the determinants of new firm survival using non-parametric methods and the following section concludes.

\section{Description of the dataset and methodology}

This work is based on the application of the entrepreneurship definitions and methodology of the Manual on Business Demography Statistics (Eurostat/OECD, 2007) to the Quadros de Pessoal dataset (Employment Administrative Records by the Portuguese Ministry of Labour and Social Security), which is the main data source in Portugal for the universe of employer enterprises. This resulted in the creation of a specific entrepreneurship micro dataset, in which the population of enterprises is restricted solely to the active enterprises with at least one paid employee, the so-called employer enterprise population. Entrepreneurship performance indicators were then calculated, following the work with the Entrepreneurship Indicators Programme (OECD, 2008), such as births, deaths, churn and survival rates. The database consists of an annual average of 215.903 active employer enterprises over the period 19852007, with an annual average of 36.803 births and 23.743 deaths.

The survival analysis provided in the following sections, will take place over this new entrepreneurship dataset, where only real births and deaths are accounted for. The core measure of births reflects the concept of employer enterprise birth. A birth amounts to the "creation of a combination of production factors with the restriction that no other enterprises are involved in the event" (Eurostat/OECD, 2007). A birth occurs when and enterprise starts from scratch and actually starts activity. Births do not include entries into the population 
which result from break-ups, spit-offs, mergers, restructuring of enterprises or reactivations of units which are dormant within a period of two years. This population thus consists of enterprises that have at least one paid employee in its birth year and also of enterprises that, despite existing before the year in consideration, were below the one employee threshold.

An employee enterprise death occurs when an employer enterprise stops having employees. Deaths do not include exits from the population due to mergers, take-overs, break-ups or restructuring of a set of enterprises. Moreover, deaths do not include exits from a subpopulation if it results from a change of activity. We have tried to identify those situations in order to remove them from the population, according to Eurostat/OECD's methodology. Therefore, a death can occur because the enterprise ceases to trade or because it shrinks below the one employee threshold. The manual recommends waiting for two years after the reference period to allow for reactivations, before deaths are calculated.

\section{Brief overview of entrepreneurship performance and survival in Portugal}

Turbulence is a natural consequence of the chase for new business opportunities as resources are rapidly reallocated from unsuccessful to successful enterprises and to growing areas of business, therefore being considered a natural source of dynamism. These firm dynamics, that is, the pace at which firms are starting up and closing down is a commonly used measure of the level of entrepreneurial activity in an economy. This reflects the Schumpeterian notion of "creative destruction", that is, the level of turbulence in the economy that leads to the commercialisation of new innovative ideas and thus to economic growth. The churn rate is one type of indicator used for the measurement of turbulence. It is viewed as an economy's ability to expand and adjust its structure of production to the market's changing needs and is given by the sum of birth and death rates (Eurostat/OECD, 2007).

One of the most robust stylized facts of competitive industry dynamics is that there is a high level of entry and exit, which occurs simultaneously in any given year. In particular, for markets where entry occurs more intensively, exit flows tend to be more prominent, as well as churning at the bottom of the size distribution (Geroski, 1995). Portugal traditionally exhibits some of the highest levels of entry and exit rates in Europe (Eurostat, 2009; INE, 2009; Scarpetta et al., 2002; Cabral, 2007). More than a quarter of firms in a given year are either being created or destroyed (according to Table 2, during the period 1987-2005, the average churn rate has been 28,5\%).

Churn rates vary significantly across sectors in most countries (Bartelsman et al., 2005), as industry structure is likely to influence significantly the rate of start-ups and close-downs. An economy heavily based in services, such as Portugal, is more likely to have higher start-up and close-down rates due to a generally higher number of small enterprises in the economy. The period 2001 to 2005 indicates a stabilisation towards less turbulence, as a consequence of the reduction of both total birth and death rates (Table 1 ).

Another widely known stylized fact is that the churn rate is greater in the service sector than in manufacturing, especially if weighted by employment. This is behaviour is also observed for Portugal (Figure 1) in line with other countries (Bartelsman et al., 2005) and Spain (López-Garcia and Puente, 2006; Núñez, 2004). During this period, the change of economic structure towards the service sector and the smaller average size of entrants can explain part of this dynamics (Sarmento and Nunes, 2009). 
Figure 1: Churn rate by broad sectors

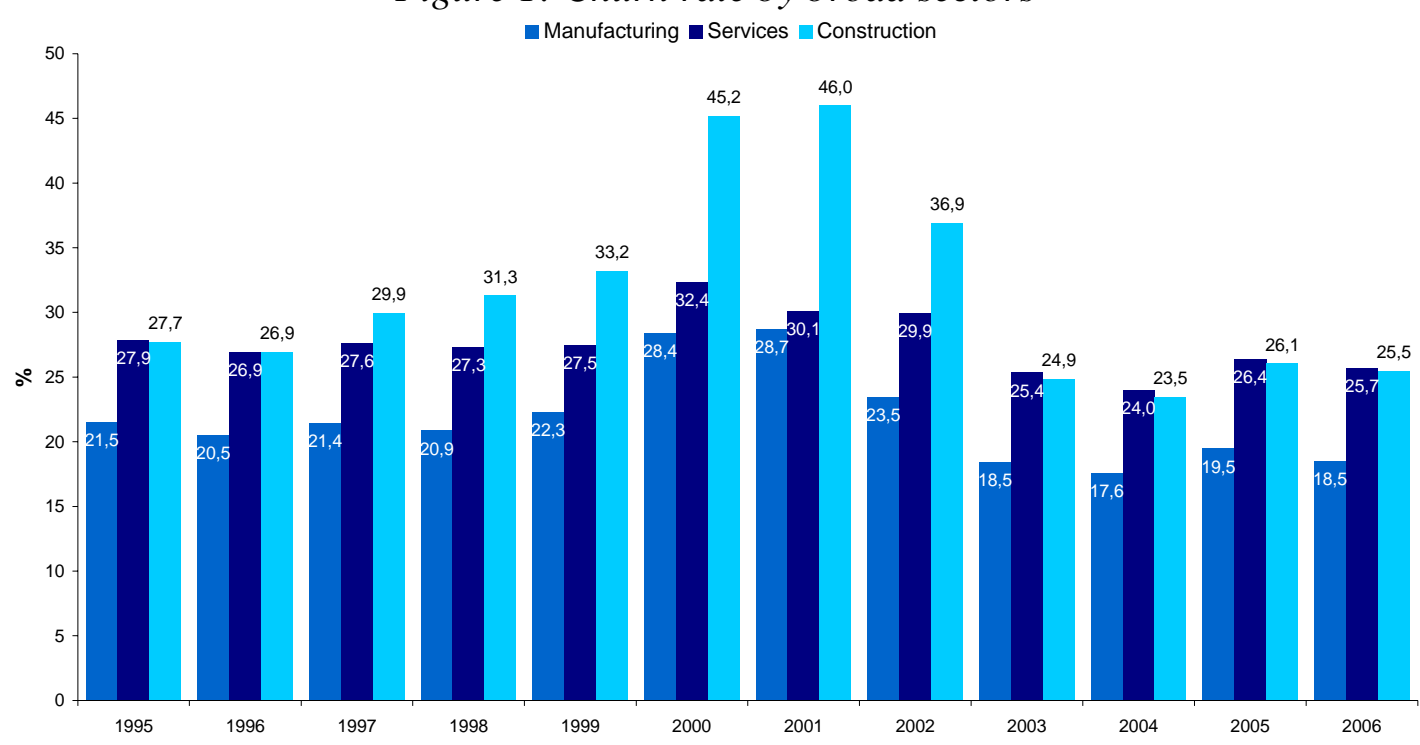

Source: Own calculations based on Quadros de Pessoal, GEP, MTSS.

Table 1: Average births and death rates and correlations of births and deaths by sector at one level letter (A-O) of the Classification of Portuguese Activities (CEA Rev.2.1. ${ }^{1}$ )

\begin{tabular}{|c|c|c|c|c|c|c|}
\hline 1995-2005 & $\begin{array}{c}\text { Average } \\
\text { Birth rate } \\
(\%)\end{array}$ & $\begin{array}{c}\text { Average } \\
\text { Death rate } \\
(\%)\end{array}$ & \begin{tabular}{|c|} 
Average \\
Churn rate \\
$(\%)$ \\
\end{tabular} & \begin{tabular}{|c} 
Pearson \\
Correlation
\end{tabular} & $\begin{array}{c}\text { Two-tailed } \\
\text { p-value }\end{array}$ & \\
\hline Agriculture, farming of animals, hunting and forestry & 20,8 & 13,2 & 34,1 & 97,8 & $<0,0001$ & *** \\
\hline Fishing & 33,1 & 15,4 & 48,5 & 98,9 & $<0,0001$ & *** \\
\hline Mining and quarrying & 11,7 & 8,7 & 20,4 & 67,7 & 0,022 & ** \\
\hline Manufacturing & 11,9 & 10,2 & 22,2 & 67,3 & 0,023 & ${ }^{* *}$ \\
\hline Production of electricity, of gas and of water supply & 16,6 & 7,8 & 24,4 & 45,5 & 0,159 & \\
\hline Construction & 19,2 & 13,1 & 32,3 & 84,7 & 0,001 & *** \\
\hline $\begin{array}{l}\text { Wholesale and retail trade; repair of motor vehicles, } \\
\text { motorcycles and personal and household goods }\end{array}$ & 14,6 & 11,2 & 25,8 & 87,9 & 0,000 & *** \\
\hline Hotels and restaurants & 17,8 & 13,6 & 31,4 & 93,1 & $<0,0001$ & *** \\
\hline Transport, storage and communication & 18,4 & 10,5 & 28,9 & 79,2 & 0,004 & *** \\
\hline Financial intermediation & 14,9 & 8,7 & 23,7 & 71,7 & 0,013 & ** \\
\hline Real estate, renting and business activities & 20,0 & 11,1 & 31,2 & 97,8 & $<0,0001$ & *** \\
\hline $\begin{array}{l}\begin{array}{l}\text { Public administration and defence; compulsory social } \\
\text { security }\end{array} \\
\text { a }\end{array}$ & 43,8 & 15,8 & 59,6 & 99,7 & $<0,0001$ & *** \\
\hline Education & 15,9 & 8,2 & 24,1 & 90,2 & 0,00 & *** \\
\hline Health and social work & 14,1 & 6,3 & 20,4 & 90,6 & 0,00 & *** \\
\hline other community, social and personal service activities & 18,3 & 11,4 & 29,6 & 96,2 & $<0,0001$ & *** \\
\hline 2001-2005 & $\begin{array}{c}\text { Average } \\
\text { Birth rate } \\
(\%) \\
\end{array}$ & $\begin{array}{c}\text { Average } \\
\text { Death rate } \\
(\%) \\
\end{array}$ & \begin{tabular}{|c|} 
Average \\
Churn rate \\
$(\%)$ \\
\end{tabular} & \begin{tabular}{|c} 
Pearson \\
Correlation
\end{tabular} & $\begin{array}{c}\text { Two-tailed } \\
\text { p-value }\end{array}$ & \\
\hline Agriculture, farming of animals, hunting and forestry & 23,7 & 13,2 & 37,0 & $99,2 \%$ & 0,001 & *** \\
\hline \begin{tabular}{|l} 
Fishing \\
Mining and quarrying \\
\end{tabular} & $\begin{array}{l}40,9 \\
10,8 \\
\end{array}$ & $\begin{array}{c}15,0 \\
9,1 \\
\end{array}$ & $\begin{array}{l}55,9 \\
19,9 \\
\end{array}$ & $\begin{array}{l}99,3 \% \\
94,5 \% \\
\end{array}$ & $\begin{array}{l}0,001 \\
0,015 \\
\end{array}$ & $\begin{array}{l}* * * \\
* * \\
\end{array}$ \\
\hline Manufacturing & 11,4 & 10,2 & 21,6 & $93,2 \%$ & 0,021 & ** \\
\hline Production of electricity, of gas and of water supply & 17,4 & 8,1 & 25,5 & $11,4 \%$ & 0,855 & \\
\hline \begin{tabular}{|l} 
Construction \\
\end{tabular} & 17,9 & 13,4 & 31,3 & $95,6 \%$ & 0,011 & *** \\
\hline $\begin{array}{l}\text { Wholesale and retail trade; repair of motor vehicles, } \\
\text { motorcycles and personal and household goods }\end{array}$ & 14,0 & 11,2 & 25,2 & $66,3 \%$ & 0,223 & \\
\hline Hotels and restaurants & 16,9 & 13,4 & 30,3 & $75,2 \%$ & 0,142 & \\
\hline Transport, storage and communication & 17,8 & 10,3 & 28,1 & $-36,9 \%$ & 0,541 & \\
\hline Financial intermediation & 14,6 & 8,2 & 22,8 & $-33,8 \%$ & 0,578 & \\
\hline Real estate, renting and business activities & 19,1 & 11,1 & 30,2 & $95,4 \%$ & 0,012 & ** \\
\hline $\begin{array}{l}\begin{array}{l}\text { Public administration and defence; compulsory social } \\
\text { security }\end{array} \\
\text { ing }\end{array}$ & 53,7 & 17,5 & 71,2 & $99,8 \%$ & 0,000 & $* * *$ \\
\hline \begin{tabular}{|l} 
Education \\
Health and social work
\end{tabular} & $\begin{array}{l}17,7 \\
12,8\end{array}$ & $\begin{array}{l}8,2 \\
5,8\end{array}$ & $\begin{array}{l}25,9 \\
18,6\end{array}$ & $\begin{array}{l}97,0 \% \\
49,1 \%\end{array}$ & $\begin{array}{l}0,006 \\
0,401\end{array}$ & $* * *$ \\
\hline Other community, social and personal service activities & 18,1 & 11,2 & 29,2 & $90,4 \%$ & 0,035 & ** \\
\hline
\end{tabular}

Source: Own calculations based on Quadros de Pessoal, GEP, MTSS.

Note: $* * * 1 \%$ significance level, $* * 5 \%$ significance level and * $10 \%$ significance level

Throwing additional light on cross-sectional differences in market conditions, one finds that entry and exit rates are highly correlated across industries (Table 1). Thus, industries with higher than average entry rates also exhibit higher than average exit rates (Cabral, 2007),

\footnotetext{
${ }^{1}$ Classification of Economic Activities, revision 2.1, compatible with ISIC REv. 3.
} 
corroborating the idea that "entry barriers are exit barriers" (Mata et al., 1995). We find that across all sectors, at the one letter level, there is a considerably high correlation for the period 1995-2005, with the exception of the sector "Production and distribution of electricity, gas and water", due to its particular market structure where heavily regulation and legal monopolies are often common. We can also observe the overall decrease in birth, death and churn rates after 2000, in the lower part of Table 1.

In line with other countries, the rotation of firms also decreases with firm's size, where smaller firms tend to have more volatile dynamics. Churn rates for small enterprises are at least three times larger than those of medium sized enterprises and always larger than the total economy’s churn rate over the whole period considered.

Table 2: Churn rates according to size class

\begin{tabular}{|c|c|c|c|c|}
\hline & \multirow{2}{*}{\multicolumn{4}{|c|}{ Churn rate }} \\
\hline & & & & \\
\hline & $\begin{array}{l}\text { Small enterprises } \\
(<50 \text { employees })\end{array}$ & $\begin{array}{c}\text { Medium } \\
\text { enterprises } \\
(50-249) \\
\end{array}$ & $\begin{array}{c}\text { Large } \\
\text { enterprises } \\
(>250) \\
\end{array}$ & $\begin{array}{c}\text { Churn rate } \\
\text { (total } \\
\text { economy) }\end{array}$ \\
\hline Year & \multicolumn{4}{|c|}{$\%$} \\
\hline 1987 & 29,2 & 6,3 & 2,9 & 28,0 \\
\hline 1988 & 32,1 & 6,6 & 4,8 & 30,9 \\
\hline 1989 & 34,7 & 7,5 & 4,0 & 33,4 \\
\hline 1990 & 29,8 & 7,1 & 4,4 & 28,7 \\
\hline 1991 & 29,8 & 8,2 & 6,7 & 28,8 \\
\hline 1992 & 29,1 & 8,8 & 4,0 & 28,2 \\
\hline 1993 & 32,2 & 10,7 & 5,1 & 31,4 \\
\hline 1994 & 35,3 & 9,4 & 8,3 & 34,4 \\
\hline 1995 & 27,3 & 6,8 & 4,1 & 26,7 \\
\hline 1996 & 26,4 & 6,5 & 3,8 & 25,8 \\
\hline 1997 & 27,6 & 7,1 & 4,4 & 26,9 \\
\hline 1998 & 27,3 & 6,5 & 5,2 & 26,7 \\
\hline 1999 & 27,9 & 7,0 & 6,4 & 27,3 \\
\hline 2000 & 34,2 & 8,1 & 5,6 & 33,5 \\
\hline 2001 & 33,0 & 9,3 & 7,1 & 32,4 \\
\hline 2002 & 30,6 & 6,8 & 6,5 & 30,0 \\
\hline 2003 & 24,6 & 6,9 & 5,2 & 24,2 \\
\hline 2004 & 23,4 & 6,2 & 5,2 & 23,0 \\
\hline \multirow[t]{2}{*}{2005} & 27,7 & 7,9 & 5,9 & 27,28 \\
\hline & \multicolumn{4}{|c|}{ Average churn rate } \\
\hline 1987-2005 & $29,2 \%$ & $7,6 \%$ & $5,3 \%$ & $28,5 \%$ \\
\hline $1987-2000$ & $30,1 \%$ & $7,6 \%$ & $5,0 \%$ & $29,3 \%$ \\
\hline 2000-2005 & $28,7 \%$ & $7,6 \%$ & $5,9 \%$ & $28,2 \%$ \\
\hline
\end{tabular}

Source: Own calculations based on Quadros de Pessoal, GEP, MTSS.

At the regional level, the churn rate is also decreasing especially after 2001, for most regions (29,3\% for $1987-2000$ and $24,8 \%$ from 2001-2005). The churn rate is the highest in the Algarve, Alentejo, Açores and Norte (Table 3).

Table 3: Average churn rates by region

\begin{tabular}{|c|c|c|}
\cline { 2 - 3 } \multicolumn{1}{c|}{} & $\mathbf{1 9 8 7 - 2 0 0 0}$ & $\mathbf{2 0 0 1 - 2 0 0 5}$ \\
\hline Norte & $30,1 \%$ & $29,4 \%$ \\
Algarve & $34,7 \%$ & $29,4 \%$ \\
Centro & $28,8 \%$ & $25,1 \%$ \\
Lisboa & $27,1 \%$ & $26,2 \%$ \\
Alentejo & $31,8 \%$ & $26,6 \%$ \\
Açores & $28,0 \%$ & $25,5 \%$ \\
Madeira & $29,4 \%$ & $27,3 \%$ \\
\hline Total & $29,3 \%$ & $24,8 \%$ \\
\hline
\end{tabular}

Source: Own calculations based on Quadros de Pessoal, GEP, MTSS. 
As survival rates tend to be related to firm size and firm age, we now turn to the analysis of the annual share of different enterprise cohorts according to longevity. In Figures 2 and 3 it is possible to observe the influence of enterprise's birth and death cycles in Portugal.

Figure 2: Share of 1 to 5 year old enterprises in total population (\%)

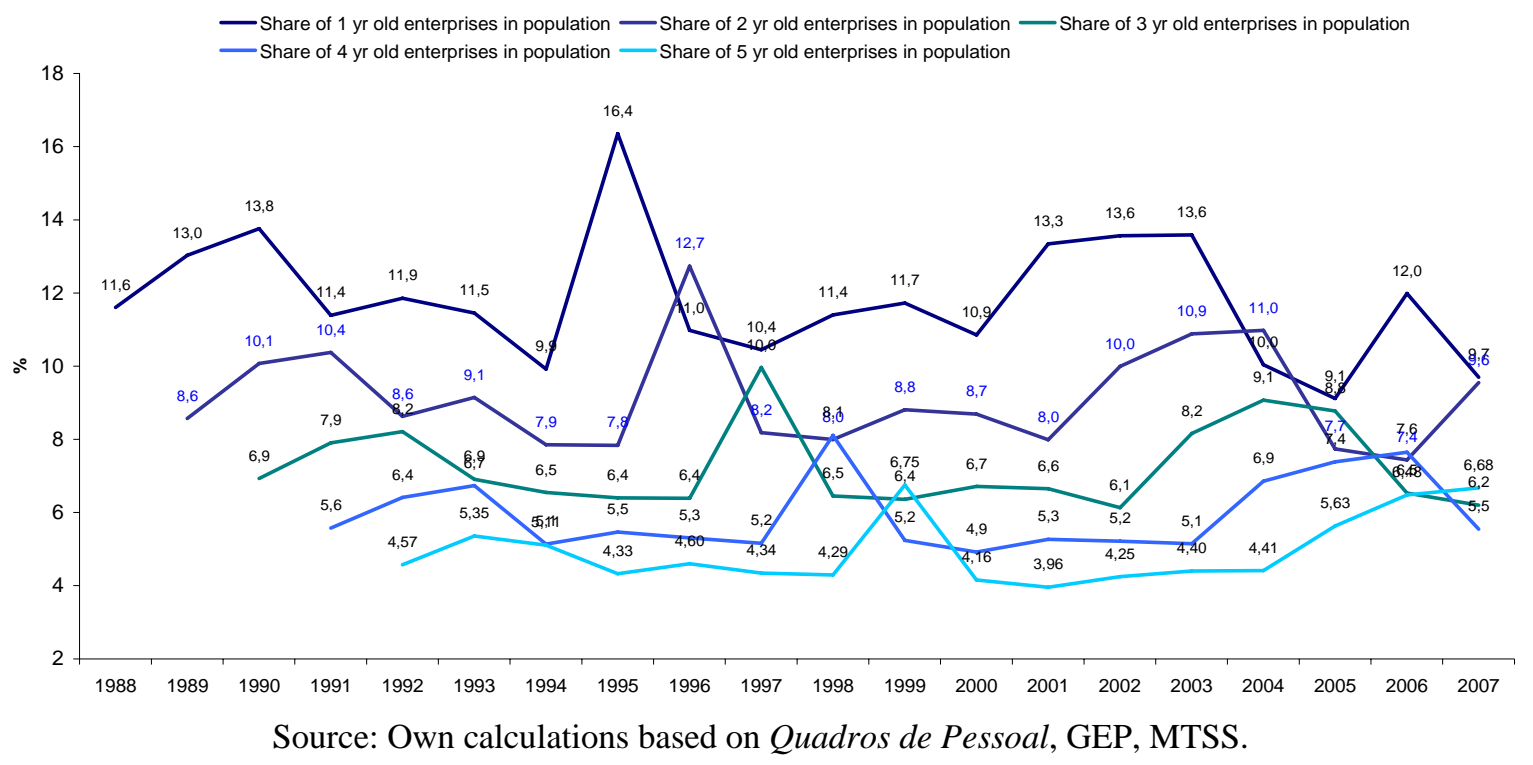

The consideration of survival indicators is also important, as they give a first indication of the performance of newly born firms. We have also followed the Eurostat/OECD's Manual (2007) for the computation of survival rates.

Survival rates of Portuguese start-ups have been rising, in particular since the late 1990s, resulting in a stronger performance and in an increasing role of new small firms in the Portuguese economy.

Figure 3: Employer Enterprises Survival rates

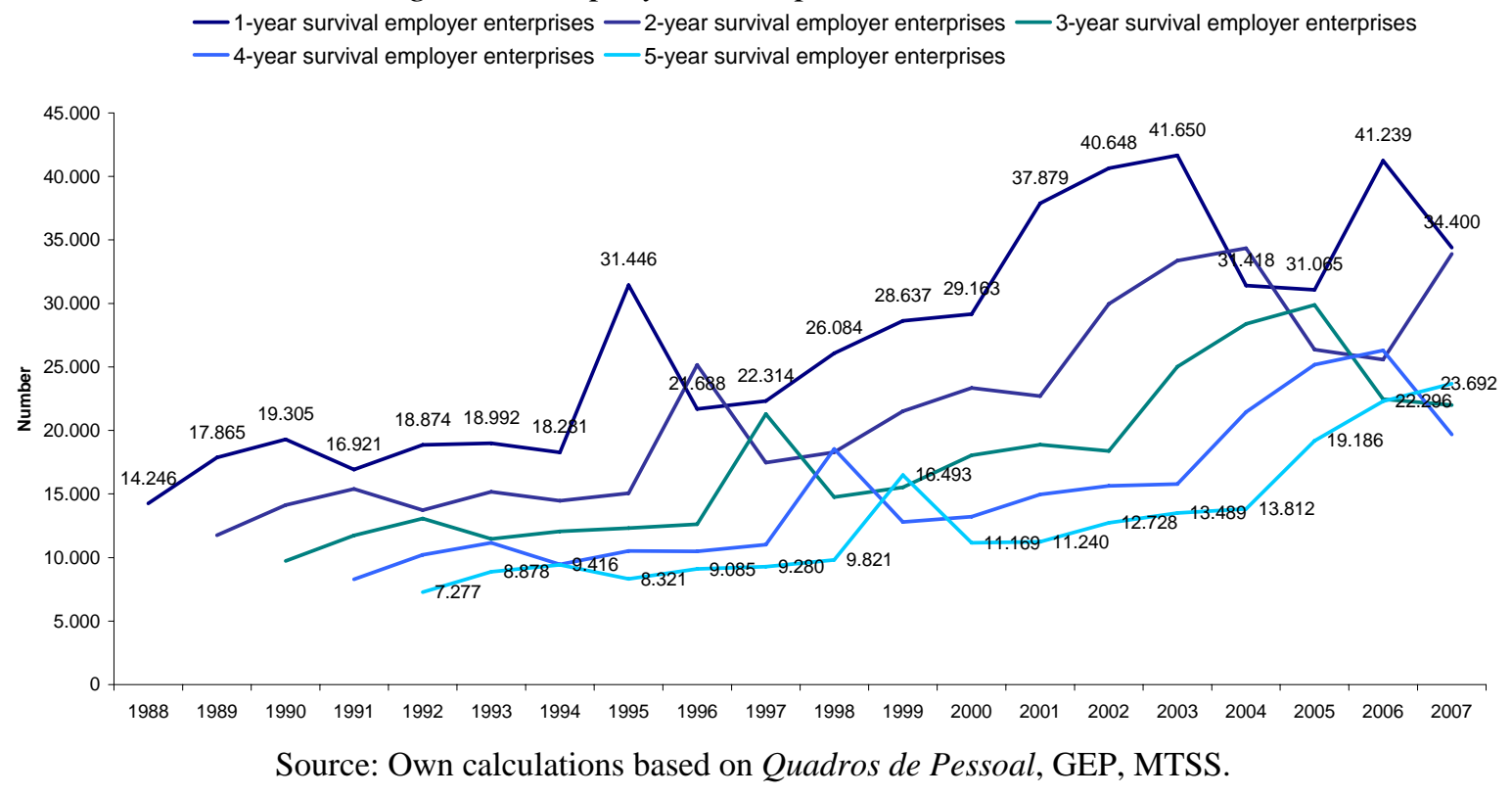


Eurostat (2009) reports that for a group of 16 countries, including Portugal, an average of $50 \%$ of all enterprises born in 2001 survived to 2006. According to our data for Portugal, the survival rate is lower than the reported EU's average. Only 41,1\% born in 2001 survived through 2006. The 5-year survival rate for enterprises born in 2002 and still active in 2007 in Portugal was 43,3\% and 1-year the survival rate for enterprises born in 2006 which survived through 2007 is 78,2\% (Table 4).

Table 4: Survival rates for employer enterprises according to the birth year

\begin{tabular}{|l|rrrrr|}
\cline { 2 - 6 } \multicolumn{1}{c|}{} & \multicolumn{5}{c|}{$\begin{array}{c}\text { Survival rate (\%) } \\
\text { Births in year: }\end{array}$} \\
\cline { 2 - 6 } & $\mathbf{2 0 0 2}$ & $\mathbf{2 0 0 3}$ & $\mathbf{2 0 0 4}$ & $\mathbf{2 0 0 5}$ & $\mathbf{2 0 0 6}$ \\
\hline 1-year survival & 76,1 & 75,8 & 77,9 & 75,2 & $\mathbf{7 8 , 2}$ \\
2-year survival & 62,8 & 63,6 & 64,1 & $\mathbf{6 1 , 8}$ & \\
3-year survival & 54,6 & 54,2 & $\mathbf{5 5 , 2}$ & & \\
4-year survival & 48,1 & $\mathbf{4 7 , 5}$ & & & \\
5-year survival & $\mathbf{4 3 , 3}$ & & & & \\
\hline
\end{tabular}

Source: Own calculations based on Quadros de Pessoal, GEP, MTSS.

For most EU member states, higher birth rates, bring about lower survival rates and vice-versa (Eurostat, 2009). Over time, we can observe the same effect in Portugal (Figure 4), in particular after 2000 when decreasing birth rates were accompanied by increasing survival rates. This result is also verified for all survival years up to the 5 year limit considered in this analysis.

Figure 4: Enterprise birth rates and 2-year survival rates, 1989-2007

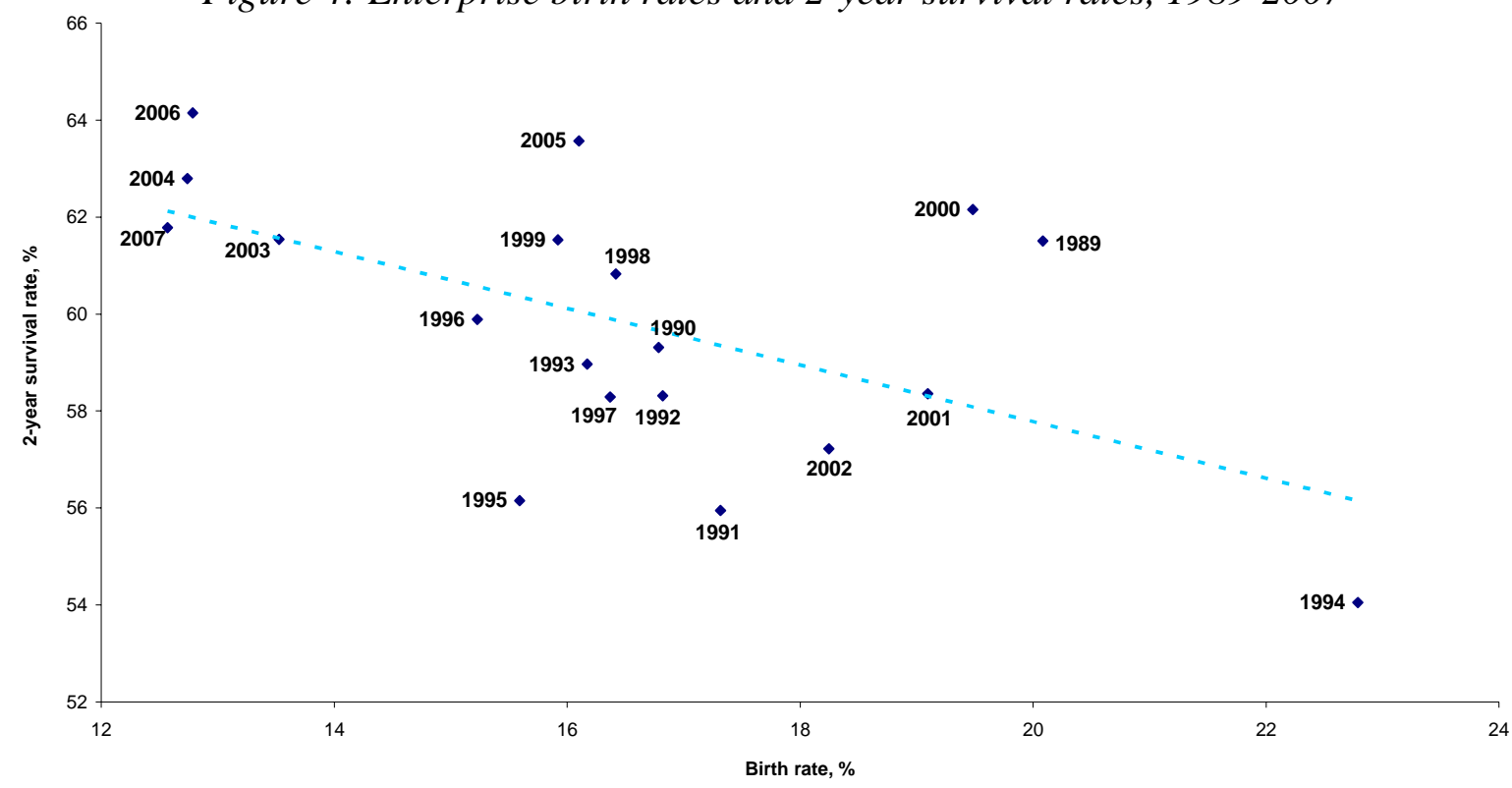

Source: Own calculations based on Quadros de Pessoal, GEP, MTSS.

\section{Non-parametric analysis of survival}

This next section consists of an econometric analysis of new firm survival that draws extensively on the survival analysis literature in industrial economics. The positive and high observed correlation between birth and death rates (Table 1) may be the result of new firms displacing old obsolete enterprises, in the so-called creative destruction process. But it also 
could be the result of higher failure rates amongst newly born enterprises during their first years of activity, as a consequence of the natural market selection, which rewards the more efficient firms. Such hypothesis, also previously studied for Portugal (Mata et al., 1995), Italy (Giovannetti, 2007) and Spain (Lopez-Garcia and Puente, 2006), will be tested applying a survival analysis which estimates survival and hazard rates over time.

\subsection{Modelling survival and hazard functions}

The survivor function reports the probability of a firm of surviving beyond time $t$ (the moment of observation), that is the probability that there is no failure event (a "death") prior to $t$. The function is equal to one at time $t=0$ and decreases towards zero as time $(t)$ goes to infinity. Considering $T$ a non-negative variable, denoting the time to a failure event ("death"), in this case given by the time taken by an enterprise to exit the market from the moment of entry. The survivor function is thus represented by:

$$
S(t)=1-F(t)=\operatorname{Pr}(T>t)
$$

With $F(t)=\operatorname{Pr}(T \leq t)$ being the cumulative distribution function.

The hazard function or the conditional failure rate is the instantaneous rate of failure. It is the (limiting) probability that the failure event ("death”) event occurs in a given interval, conditional upon the subject having survived to the beginning of that interval, divided by the width of the interval:

$$
h(t)=\lim _{\Delta t \rightarrow 0} \frac{\operatorname{Pr}(t+\Delta t>T>t \mid T>t)}{\Delta t}=\frac{f(t)}{S(t)},
$$

Where $f(t)=\frac{d F(t)}{d t}=\frac{d\{1-S(t)\}}{d t}=-S^{\prime}(t)$ is the density function.

The hazard rate measures the rate at which risk is accumulated and can vary from zero (no risk at all) to infinity. The integral from 0 to $t$ of the hazard rates is known as the cumulative hazard function $(H(t))$. It records the number of times failures were observed over a given time period.

In practice, to estimate the survivor function, $s(t)$, that is the probability of survival past time $t$ or, equivalently, the probability of failure after $t$, the non-parametric Kaplan-Meier estimator was applied. For a dataset with observed failure times, $t_{1}, \ldots, t_{k}$, where $k$ is the number of distinct failure times observed in the data, the Kaplan-Meier estimate at any time $t$ is given by:

$$
\hat{S}(t)=\prod_{j \mid t_{j} \leq t}\left(\frac{n_{j}-d_{j}}{n_{j}}\right)
$$

Where $n_{j}$ is the number of enterprises at risk at time $t_{j}$ and $d_{j}$ is the number of failures at time $t_{j}$. The product is done for all the failure periods, departing from time $t$. 
The most common estimator for the cumulative hazard rate is the non-parametric NelsonAalen estimator, which is defined by the sum of the instantaneous ratio of the failures over the number of enterprises at risk. This estimator is thus given by:

$$
\bar{H}(t)=\sum_{j t_{j} \leq t} \frac{d_{j}}{n_{j}}
$$

\subsection{Survival and hazard functions across regions, size class and sectors}

Our analysis is designed to observe how failure rates relate to the geography region, dimension or industry membership. The usage of life tables allows a structured method of analysis of the number of firms that "die", conditional on their age, that is, it represents the probability of failure given that the firm has survived a certain given number of years (Table 5).

There is extensive evidence in the literature that failure rates decline with age (Mata et al., 1995; Dunne et al., 1989; Mahmood, 1992; Audretsch and Mahmood, 1994 and 1995). In Portugal, during the period 1987-2005, approximately 86\% of all the employer enterprise births remained active after one year of "life". These results are in line with the OECD's estimates, where around $60 \%$ to $80 \%$ of birth enterprises survive beyond the first two years of activity, and only around $40 \%$ to $50 \%$ of total birth enterprises survive beyond the seventh year of activity. Eurostat (2009) also reported for the whole business economy, that roughly half of the enterprises survive during their first 5 years.

A more detailed look into our survival data, shows that the estimated median duration of a new born enterprise lies between 5 and 6 years. After 18 years of activity, only 22\% of employer enterprise start-ups were still alive or equivalently, almost $78 \%$ had already exited the market.

Table 5: Life Table for Employer Enterprise Births, 1987-2005

\begin{tabular}{|c|c|c|c|c|c|c|c|}
\hline \multirow{2}{*}{ Time } & \multirow{2}{*}{ Observations } & \multirow{2}{*}{ Deaths } & \multirow{2}{*}{$\begin{array}{c}\text { Censured } \\
\text { Observations }\end{array}$} & \multicolumn{2}{|c|}{ Kaplan-Meier } & \multicolumn{2}{|c|}{ Nelson Aalen } \\
\hline & & & & $\begin{array}{l}\text { Survivor } \\
\text { Function }\end{array}$ & $\begin{array}{c}\text { Failure } \\
\text { Function }\end{array}$ & $\begin{array}{c}\text { Hazard } \\
\text { Rate }\end{array}$ & $\begin{array}{l}\text { Cumulative } \\
\text { Hazard Rate }\end{array}$ \\
\hline \multirow{2}{*}{ Years } & \multirow{2}{*}{$\mathrm{n}^{\mathrm{o}}$} & \multirow{2}{*}{$\mathrm{n}^{\mathrm{o}}$} & \multirow{2}{*}{$\mathrm{n}^{\mathrm{o}}$} & $\%$ & $\%$ & $\%$ & $\%$ \\
\hline & & & & $\mathrm{P}(\mathrm{S})$ & $100-\mathrm{P}(\mathrm{S})$ & $P(D)$ & $\sum P(D)$ \\
\hline 1 & 451.041 & 63.088 & $24000 *$ & $86,0 \%$ & $14,0 \%$ & $14,0 \%$ & $14,0 \%$ \\
\hline 2 & 364.233 & 46.351 & $22000 *$ & $75,1 \%$ & $24,9 \%$ & $10,9 \%$ & $26,7 \%$ \\
\hline 3 & 295.786 & 32.973 & $28000 *$ & $66,7 \%$ & $33,3 \%$ & $8,4 \%$ & $37,9 \%$ \\
\hline 4 & 235.002 & 23.655 & $24000 *$ & $60,0 \%$ & $40,0 \%$ & $6,7 \%$ & $47,9 \%$ \\
\hline 5 & 187.102 & 17.353 & $19000 *$ & $54,4 \%$ & $45,6 \%$ & $5,6 \%$ & $57,2 \%$ \\
\hline 6 & 150.840 & 12.966 & $12000 *$ & $49,7 \%$ & $50,3 \%$ & $4,7 \%$ & $65,8 \%$ \\
\hline 7 & 125.525 & 10.059 & $11000 *$ & $45,8 \%$ & $54,2 \%$ & $4,0 \%$ & $73,8 \%$ \\
\hline 8 & 104.121 & 7.735 & 9.613 & $42,4 \%$ & $57,6 \%$ & $3,4 \%$ & $81,2 \%$ \\
\hline 9 & 86.773 & 6.089 & 7.943 & $39,4 \%$ & $60,6 \%$ & $3,0 \%$ & $88,3 \%$ \\
\hline 10 & 72.741 & 5.068 & 7.491 & $36,6 \%$ & $63,4 \%$ & $2,8 \%$ & $95,2 \%$ \\
\hline 11 & 60.182 & 4.172 & $11000^{*}$ & $34,1 \%$ & $65,9 \%$ & $2,5 \%$ & $102,2 \%$ \\
\hline 12 & 45.130 & 3.037 & 6.150 & $31,8 \%$ & $68,2 \%$ & $2,3 \%$ & $108,9 \%$ \\
\hline 13 & 35.943 & 2.422 & 5.626 & $29,7 \%$ & $70,3 \%$ & $2,2 \%$ & $115,6 \%$ \\
\hline 14 & 27.895 & 1.681 & 5.546 & $27,9 \%$ & $72,1 \%$ & $1,8 \%$ & $121,7 \%$ \\
\hline 15 & 20.668 & 1.133 & 4.733 & $26,4 \%$ & $73,7 \%$ & $1,5 \%$ & $127,1 \%$ \\
\hline 16 & 14.802 & 805 & 5.361 & $24,9 \%$ & $75,1 \%$ & $1,4 \%$ & $132,6 \%$ \\
\hline 17 & 8.636 & 490 & 4.418 & $23,5 \%$ & $76,5 \%$ & $1,4 \%$ & $138,2 \%$ \\
\hline 18 & 3.728 & 228 & 3.500 & $22,1 \%$ & $77,9 \%$ & $1,4 \%$ & $144,4 \%$ \\
\hline
\end{tabular}

Source: Own calculations based on Quadros de Pessoal, GEP, MTSS.

Notes: * Approximate values. 
The smoothed hazard estimate or unconditional hazard function for the total economy presents an inverted U-shape with its maximum around the sixth year of activity (Figure 5). After firms' entry into the market, the conditional probability of failure increases continuously until the sixth year, with hazard rates declining steeply thereafter. Young new firms are posited to be less efficient and are thus more likely to fail than firms that have acquired market experience. Such pattern is similar to that found in other economies, such as Italy (Audretsch et al., 1999), the UK (Bhattacharjee, 2005), Germany (Wagner, 1994), UK, Italy and the US (Bartelsman et al., 2005) and Spain (López-Garcia and Puente, 2006). In all these cases, the maximum of the unconditional hazard function is reached before the sixth year, indicating that Portuguese firms keep on failing for a longer period, before the hazard rate starts declining.

Figure 5: Smoothed hazard estimate for the total economy, 1987-2005

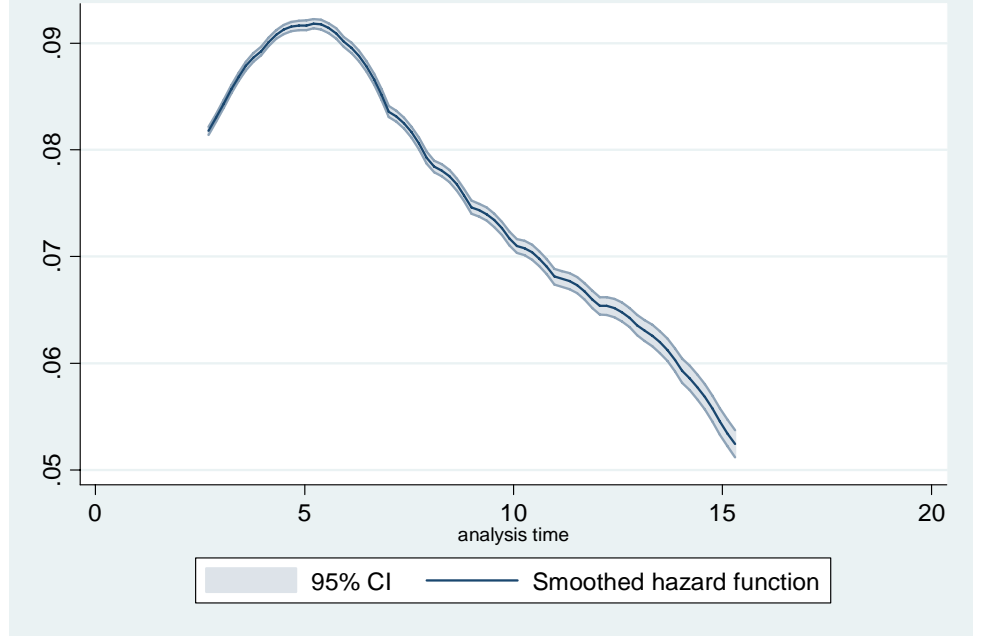

Source: Own calculations based on Quadros de Pessoal, GEP, MTSS.

\subsubsection{Survival and hazard functions across regions}

Table 6 presents the results for the non-parametric estimation, for each of the seven Portuguese NUTII regions. This framework explores the relationship between age and the regional hazard of exit.

In line with the results shown previously for the total economy, over $85 \%$ of newly born employer enterprises remain active during their first year of activity in all regions. The oneyear survival rate varies from a low of $85 \%$ in the Açores, to a high of $87,5 \%$ in the Centro region, meaning that the new born enterprises died more prematurely in Açores than in other Portuguese regions.

Table 2 also reveals that the survival gap between the two extreme regions grows systematically with time. Within 6 years of activity, the region Norte is the only one with less than $50 \%$ of enterprise survival probability, lagging behind all other regions in terms of enterprise survival. On the other hand, Centro has a higher survival rate than the economy's average. It is the region where more firms manage to survive longer throughout the period considered in this study.

There are also clear disparities between regions, in particular between Norte and Centro, in terms of median duration survival. At the end of the analysis period, Norte is the region that 
presents the lowest survival rate, with only $20,7 \%$ of the firms' population managing to survive after eighteen years of activity. In Centro, in turn, 27,4\% of active start-ups are still alive after 18 years.

Table 6: Survival Table for Employer Enterprise Births by NUTII region, 1987-2005

\begin{tabular}{|c|ccccccc|}
\hline Time & Norte & Centro & $\begin{array}{c}\text { Lisboa e Vale } \\
\text { do Tejo }\end{array}$ & Alentejo & Algarve & Açores & Madeira \\
\hline 1 & $85,6 \%$ & $87,4 \%$ & $85,5 \%$ & $85,8 \%$ & $85,6 \%$ & $85,1 \%$ & $86,1 \%$ \\
2 & $75,1 \%$ & $77,7 \%$ & $75,1 \%$ & $75,5 \%$ & $75,5 \%$ & $74,2 \%$ & $76,0 \%$ \\
3 & $66,5 \%$ & $70,1 \%$ & $67,0 \%$ & $67,0 \%$ & $67,7 \%$ & $67,0 \%$ & $68,3 \%$ \\
4 & $59,8 \%$ & $64,0 \%$ & $60,5 \%$ & $60,4 \%$ & $61,2 \%$ & $59,9 \%$ & $61,3 \%$ \\
5 & $54,1 \%$ & $58,9 \%$ & $55,0 \%$ & $54,9 \%$ & $55,8 \%$ & $54,5 \%$ & $56,2 \%$ \\
6 & $49,4 \%$ & $54,5 \%$ & $50,4 \%$ & $50,7 \%$ & $51,1 \%$ & $50,5 \%$ & $51,6 \%$ \\
7 & $45,3 \%$ & $50,7 \%$ & $46,6 \%$ & $46,9 \%$ & $47,2 \%$ & $46,7 \%$ & $47,5 \%$ \\
8 & $41,7 \%$ & $47,5 \%$ & $43,2 \%$ & $43,4 \%$ & $44,2 \%$ & $43,7 \%$ & $44,6 \%$ \\
9 & $38,7 \%$ & $44,5 \%$ & $40,2 \%$ & $40,5 \%$ & $41,1 \%$ & $41,2 \%$ & $41,7 \%$ \\
10 & $35,8 \%$ & $41,9 \%$ & $37,6 \%$ & $37,7 \%$ & $38,5 \%$ & $38,9 \%$ & $38,6 \%$ \\
11 & $33,0 \%$ & $39,5 \%$ & $35,1 \%$ & $35,2 \%$ & $36,2 \%$ & $36,3 \%$ & $36,6 \%$ \\
12 & $30,5 \%$ & $37,4 \%$ & $32,8 \%$ & $33,0 \%$ & $34,0 \%$ & $33,9 \%$ & $34,3 \%$ \\
13 & $28,1 \%$ & $35,3 \%$ & $30,8 \%$ & $31,0 \%$ & $32,0 \%$ & $31,3 \%$ & $31,7 \%$ \\
14 & $26,4 \%$ & $33,4 \%$ & $29,0 \%$ & $29,3 \%$ & $30,2 \%$ & $29,4 \%$ & $29,9 \%$ \\
15 & $24,8 \%$ & $31,8 \%$ & $27,4 \%$ & $27,8 \%$ & $29,0 \%$ & $28,2 \%$ & $28,2 \%$ \\
16 & $23,2 \%$ & $30,4 \%$ & $26,1 \%$ & $26,2 \%$ & $27,8 \%$ & $26,4 \%$ & $26,9 \%$ \\
17 & $21,9 \%$ & $28,9 \%$ & $24,6 \%$ & $24,9 \%$ & $25,4 \%$ & $25,4 \%$ & $26,6 \%$ \\
18 & $20,7 \%$ & $27,4 \%$ & $22,9 \%$ & $23,2 \%$ & $23,9 \%$ & $23,8 \%$ & $25,4 \%$ \\
\hline
\end{tabular}

Source: Own calculations based on Quadros de Pessoal, GEP, MTSS.

The median duration of firms at the regional level (Figure 6), is below seven years for most regions, except for Centro (around the eight year).

Figure 6: Smoothed hazard estimate by NUTII, 1987-2005

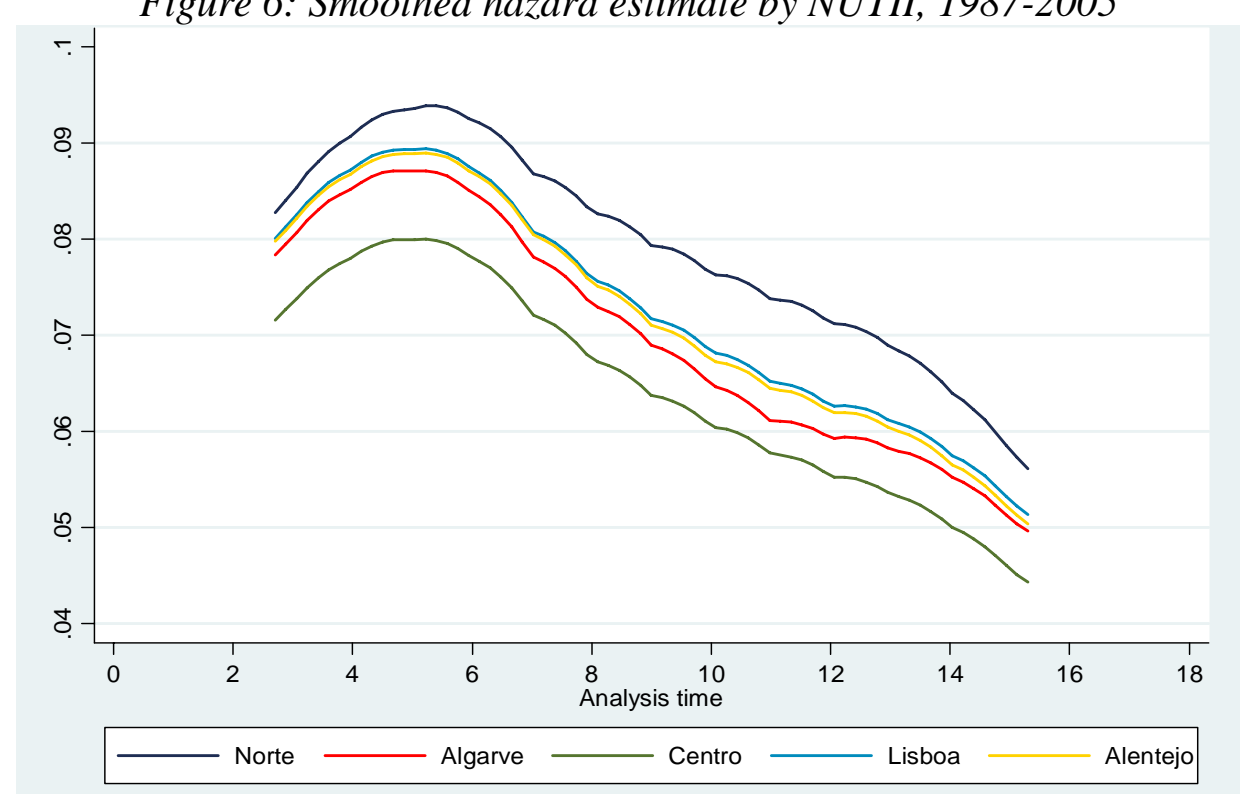

Source: Own calculations based on Quadros de Pessoal, GEP, MTSS. 
The disparities among the Portuguese regions are confirmed by equality tests. Both Log-rank and Wilcoxon (Breslow) tests allow for the rejection of the hypothesis of survival equality among regions ${ }^{2}$.

\subsubsection{Survival and hazard functions across size classes}

A general finding in the literature is that most firms start small, live small and die small. According to Eurostat (2009), Portugal has the highest share of enterprises births in the 1 to 4 employees' size class. Small firms in Portugal are also being created at a faster pace than larger firms, gaining share in both enterprise and employment (Sarmento and Nunes, 2009).

We find that smaller firms exhibit the lowest survival probability (Table 7). More than 15\% of micro firms with fewer than 5 employees "die" in the first year of activity (only around 85\% manage to survive), whereas large firms with over 250 employees, have a much higher survival rate, of 93,9\%. Differences between size classes are significant. Conditional on overcoming the first ten years, the smallest sized firms are the only ones to have a survival probability below 50\% ( $31 \%$ for the 1 to 4 size class). Over time, the gap between the smallest and the largest firms' survivor rates widens. The bigger the firm, the higher the probability of survival.

Table 7: Survival Table for Employer Enterprise Births by size class, 1987-2005

\begin{tabular}{|c|cccccc|}
\hline Time & $\mathbf{1 - 4}$ & $\mathbf{5 - 9}$ & $\mathbf{1 0 - 1 9}$ & $\mathbf{2 0 - 4 9}$ & $\mathbf{5 0 - 2 4 9}$ & $+\mathbf{+ 2 5 0}$ \\
\hline 1 & $84,9 \%$ & $90,0 \%$ & $90,1 \%$ & $89,8 \%$ & $92,0 \%$ & $93,9 \%$ \\
2 & $73,4 \%$ & $82,6 \%$ & $82,8 \%$ & $82,7 \%$ & $84,7 \%$ & $87,6 \%$ \\
3 & $64,3 \%$ & $76,5 \%$ & $76,9 \%$ & $76,6 \%$ & $78,6 \%$ & $82,8 \%$ \\
4 & $57,0 \%$ & $71,2 \%$ & $71,7 \%$ & $71,3 \%$ & $73,2 \%$ & $78,9 \%$ \\
5 & $51,0 \%$ & $66,7 \%$ & $67,2 \%$ & $66,8 \%$ & $68,9 \%$ & $74,6 \%$ \\
6 & $45,8 \%$ & $62,9 \%$ & $63,5 \%$ & $62,9 \%$ & $64,8 \%$ & $71,9 \%$ \\
7 & $41,3 \%$ & $59,5 \%$ & $60,6 \%$ & $60,3 \%$ & $62,0 \%$ & $70,7 \%$ \\
8 & $37,5 \%$ & $56,5 \%$ & $58,0 \%$ & $57,7 \%$ & $59,7 \%$ & $69,1 \%$ \\
9 & $34,1 \%$ & $53,8 \%$ & $55,7 \%$ & $55,4 \%$ & $57,1 \%$ & $65,8 \%$ \\
10 & $31,0 \%$ & $51,1 \%$ & $53,5 \%$ & $53,2 \%$ & $55,0 \%$ & $62,4 \%$ \\
11 & $28,2 \%$ & $48,6 \%$ & $51,4 \%$ & $51,3 \%$ & $52,8 \%$ & $60,6 \%$ \\
12 & $25,7 \%$ & $46,2 \%$ & $49,4 \%$ & $49,5 \%$ & $51,1 \%$ & $57,6 \%$ \\
13 & $23,4 \%$ & $43,9 \%$ & $47,5 \%$ & $47,4 \%$ & $49,1 \%$ & $55,9 \%$ \\
14 & $21,4 \%$ & $42,0 \%$ & $45,8 \%$ & $46,0 \%$ & $47,8 \%$ & $54,7 \%$ \\
15 & $19,7 \%$ & $40,5 \%$ & $44,4 \%$ & $44,5 \%$ & $46,4 \%$ & $54,0 \%$ \\
16 & $18,2 \%$ & $39,0 \%$ & $42,9 \%$ & $43,5 \%$ & $44,9 \%$ & $52,2 \%$ \\
17 & $16,7 \%$ & $37,4 \%$ & $41,9 \%$ & $41,9 \%$ & $44,0 \%$ & $50,6 \%$ \\
18 & $15,1 \%$ & $35,8 \%$ & $40,8 \%$ & $40,4 \%$ & $42,9 \%$ & $43,8 \%$ \\
\hline
\end{tabular}

Source: Own calculations based on Quadros de Pessoal, GEP, MTSS.

Differences in hazard rates across firm size classes are particularly evident in the early stages of a firm's life (Figure 7). The regional disparity, observed in the previous section, is also confirmed among different size classes. The equality tests performed allow the acceptance of the hypothesis that firms present distinct survive performances according to their dimension. The largest size class reveals some deterioration in its survival capacity after the $12^{\text {th }}$ year of activity, depicted by the "overshooting" of the hazard estimation function.

\footnotetext{
${ }^{2}$ The hypothesis being tested considers that there are no subgroup differences in survivor functions. We find the probability that the observed differences occur by chance is below 0,0 . This piece of evidence is not included in the present work, but is available at request.
} 
Figure 7: Smoothed hazard estimate by size class, 1987-2005

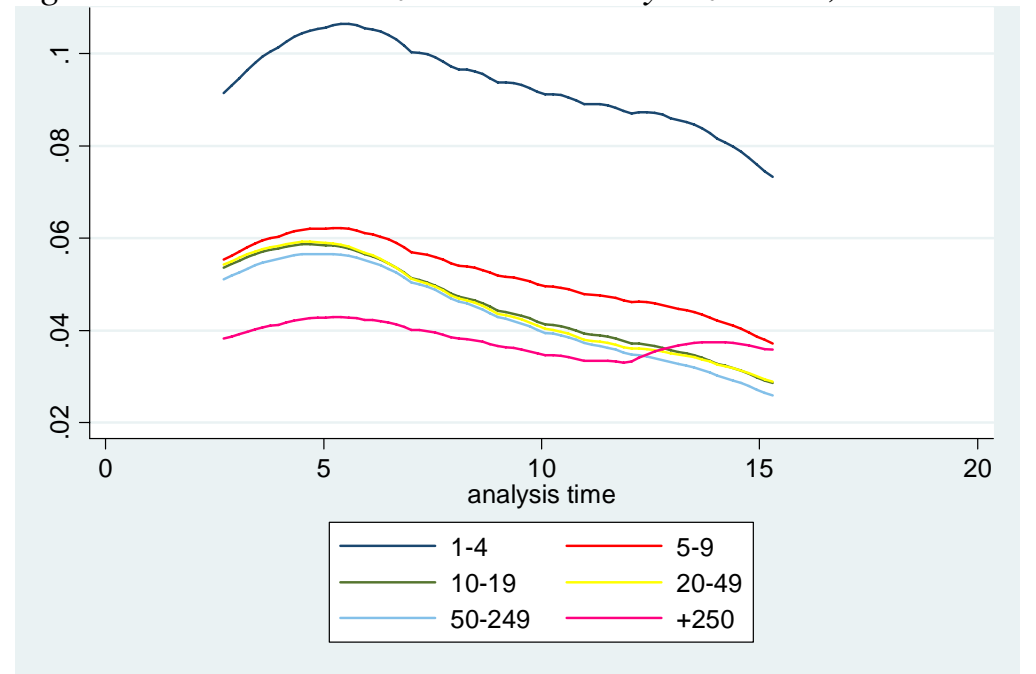

Source: Own calculations based on Quadros de Pessoal, GEP, MTSS.

\subsubsection{Survival and hazard functions across broad sectors}

Our analysis now turns to the question of whether failure rates vary according to industry membership. Table 8 shows survival rates at different lifetimes across broad sectors for a period of ten years (after 1995 due to the start of European System of Accounts of 1995, and up to 2006 due to the problems of compatibility with Classification of Economic Activities Revision 3, introduced in 2007).

Enterprises operating in the construction sector have the lowest survival probabilities over all this time period and show the greatest survival gap between the first and its tenth year of activity (a decrease of 55,1 p.p.). Its hazard peak is reached within the first 4 years of activity (Figure 4), but survival tends to decline faster than in other sectors. On the other hand, the agriculture sector has had the highest survival rates up to the fourth year of activity.

Table 8: Survival table for employer enterprise births by broad sectors, 1995-2006

\begin{tabular}{|c|cccc|}
\hline Time & $\begin{array}{c}\text { Agriculture } \\
\text { and Fishing }\end{array}$ & Construction & Manufacturing & Services \\
\hline 1 & $86,5 \%$ & $84,8 \%$ & $86,4 \%$ & $85,9 \%$ \\
2 & $76,1 \%$ & $73,3 \%$ & $75,7 \%$ & $75,4 \%$ \\
3 & $67,9 \%$ & $63,8 \%$ & $66,9 \%$ & $66,9 \%$ \\
4 & $60,3 \%$ & $56,0 \%$ & $59,4 \%$ & $60,1 \%$ \\
5 & $54,3 \%$ & $49,4 \%$ & $52,8 \%$ & $54,5 \%$ \\
6 & $49,3 \%$ & $44,2 \%$ & $47,7 \%$ & $49,8 \%$ \\
7 & $44,8 \%$ & $39,8 \%$ & $43,9 \%$ & $45,7 \%$ \\
8 & $40,9 \%$ & $36,3 \%$ & $40,4 \%$ & $42,3 \%$ \\
9 & $38,8 \%$ & $33,1 \%$ & $37,2 \%$ & $39,1 \%$ \\
10 & $36,1 \%$ & $29,7 \%$ & $34,2 \%$ & $35,7 \%$ \\
\hline
\end{tabular}

Source: Own calculations based on Quadros de Pessoal, GEP, MTSS.

The smoothed hazard estimate shows that in the service sector, the probability of "death" increases steeply within the first three years, but the hazard peak is reached sooner than in other sectors. Following this point, an increase in age, brings about a flatter probability of failure at the lower end of the distribution (Figure 8). 
The existence of disparities among the Portuguese regions is also confirmed by the equality tests performed. Both Log-rank and Wilcoxon (Breslow) tests allow for the rejection of the hypothesis of survival equality across broad sectors.

Figure 8: Smoothed hazard estimate by broad sectors

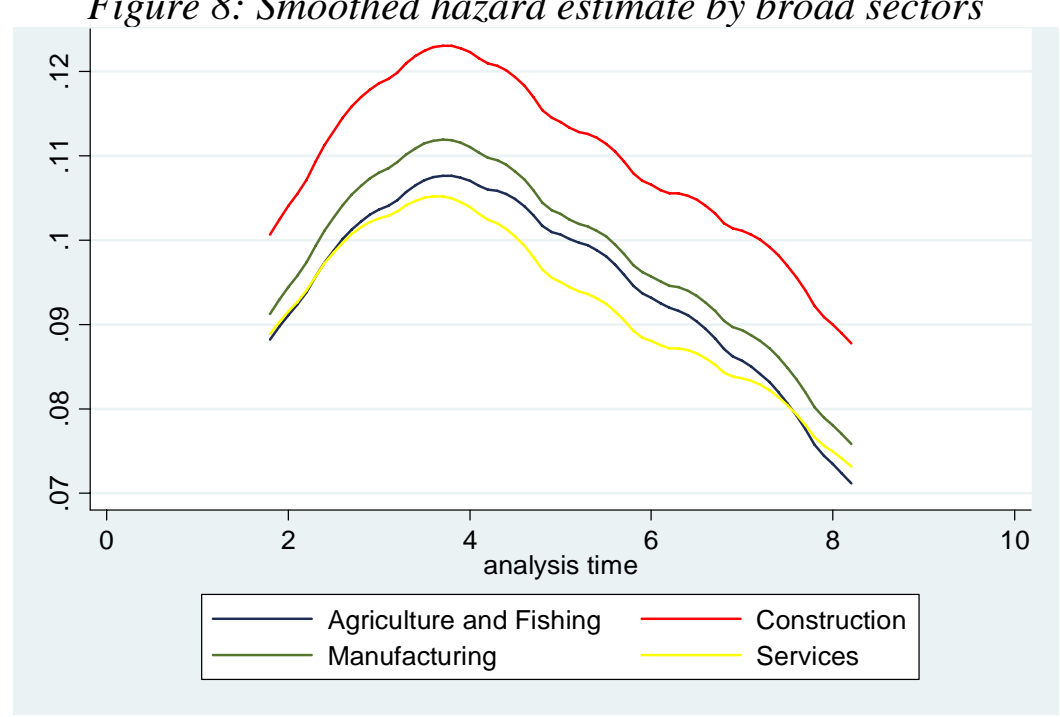

Source: Own calculations based on Quadros de Pessoal, GEP, MTSS.

\section{Final remarks}

In our analysis, we find that around $25 \%$ of enterprises entering the market fail within the first 2 years of activity and that more than $50 \%$ fail within a period of six years. We have also found that the instantaneous probability of exit is monotonically decreasing with firm size and that, after entry, the conditional probability of failure increases continuously up to the sixth year of activity.

Breaking down by region, sector and class dimension, we identify statistically significant disparities. As for the regional dimension, it is worth noting the disparities in terms of median duration survival, in particular between Norte and Centro. Within the first 6 years of activity, the Norte is the only region registering less than $50 \%$ of enterprise survival probability, lagging behind all other regions in terms of enterprise survival, while Centro is the region where firms survive longer throughout the period considered. We also observed that the survival gap between the Norte and Centro has been systematically increasing during the period.

As for the firm dimension, we found a significant relationship between size and chance of survival. This is particularly observable for new start-ups, who face the greatest uncertainty regarding market conditions (this accords to Jovanovic, 1982, who stresses post-entry learning as a fundamental determinant of firm performance and survival).

At the sectoral level, we find that firms in the construction sector exhibit the highest risk of failure. Firms in the service sector, in turn, display the highest survival rates. The services sector also exhibits a tendency for the hazard peak to be reached sooner, which means that chances of survival relating to firm age, start increasing sooner than in other broad sectors. 


\section{References}

Acs, Z. S. Desai and Klapper, L. (2008), What does "Entrepreneurship” data really show?, a comparison of the Global Entrepreneurship Monitor and the World Bank Group Datasets, World Bank, Policy Research Working Paper Series 4467.

Ahn, S. (2001), Firm dynamics and Productivity Growth: a review of micro evidence from OECD countries, OECD Economics Department Working Paper no. 297, Paris.

Audretsch, D. B. and Mahmood, T. (1995), New Firm Survival: New Results Using a Hazard Function, The Review of Economics and Statistics, LXXVII, 97-103.

Audretsch, D. B. and Mahmood, T. (1994), The Rate of Hazard Confronting New Firms and Plants in U.S. Manufacturing, Review of Industrial Organisation, no. 9, 41-56.

Audretsch, D., Santarelli, E. and Vivarelli, M. (1999), Start-up size and industrial dynamics: some evidence from Italian manufacturing, International Journal of Industrial Organization, Elsevier, Vol. 17, no. 7, 965-983.

Baldwin, J. and Gellatly, G. (2003), Inovation Strategies And Performance In Small Firms. Cheltenham, UK: Edward Elgar.

Bhattacharjee, A. (2005), Models of Firm Dynamics and the Hazard Rate of Exits: Reconciling Theory and Evidence using Hazard Regression Models, Econometrics 0503021, EconWPA.

Baptista, R., Escária, V.and Madruga, P. (2008), Entrepreneurship, regional development and job creation: the case of Portugal, Small Business Economics, no. 30, 49-58.

Baptista, R. and Carias, C. (2007), Job creation and destruction by small businesses in the Portuguese regions, IN+, presented at the European Regional Science Association, ERSA 2007.

Baptista, R. and Mendonça, J. (2007), Short and long term survival of new businesses: the role of human capital, IN+, Draft version of 2007.

Bartelsman, E.J., Scarpetta, S. and Schivardi, F. (2005), Comparative Analysis of Firm Demographics and Survival: Evidence from Micro-level Sources in OECD Countries, Industrial and Corporate Change, Vol. 14, no. 3, 365-391.

Cabral, L. (2007), Small firms in Portugal: A selective Survey of Stylized Facts, Economic Analysis and Policy Implementation, Portuguese Economic Journal, Vol. 6, no. 1, 65-88.

Cabral, L. and Mata, J. (2003), On the evolution of the firm size distribution: facts and theory, The American Economic Review, Vol. 93, no.4, 1075 - 1090.

D’Agostino, R. B., Balanger, A. and D’Agostino, Jr. (1990), A Suggestion for Using Powerful and Informative Tests of Normality, American Statistician, no. 44, 316-321.

Dunne, T., Roberts, M. J. and Samuelson, L. (1989), The Growth and Failure of U.S. Manufacturing Plants, The Quarterly Journal of Economics, MIT Press, Vol. 104, no. 4, 671-98.

Eurostat (2009), Business Demography: employment and survival, Statistics in focus, no. 70/2009

Eurostat and OECD (2007), Eurostat/OECD Manual on Business Demography Statistics.

Geroski, P. (1995), What do we know about entry?, International Journal of Industrial Organization, Vol. 13, 421-440.

Giovannetti, G., Giorgio R. and Margherita, V. (2007), Size, Innovation and Internationalization: A Survival Analysis of Italian Firms, Working Papers Series no. 2007-07, Universita' degli Studi di Firenze, Dipartimento di Scienze Economiche.

Görg , H., Strobl, E. and Ruane, F. (2000), The Determinants Of Firm Start-Up Size: A Comparison of Ireland And Portugal, Trinity Economics Papers no 20008.

Hoffmann, A. and Junge, M. (2006), Documenting Data on High-Growth Firms and Entrepreneurs across 17 countries (First Draft), FORA Working Paper, Copenhagen:FORA.

Jovanovic, B. (1982), Selection and evolution of industry, Econometrica, Vol.50, no. 3, 649-670.

Klapper, L., Lewin, A. and Delgado, J.M.Q. (2009), The impact of business environment on the business creation process, The World Bank Policy Research Working Paper Series 4937.

Klapper, L., Amit, R. and Guillén, M. (2008), Entrepreneurship and firm formation across countries, The World Bank Policy Research Working Paper Series 4313.

López-Garcia, P. and Puente, S. (2006), Business demography in Spain: determinants of firm survival, Documentos de Trabajo no. 608, Banco de España.

Mahmood, T. (1992), Does the Hazard Rate for New Plants Vary Between Low and High-Tech Industries?, Small Business Economics no.4, 201-209.

Mata. J. (1993), Entry and type of entrant: evidence from Portugal, International Journal of Industrial Organization, Vol. 11, no. 1, 101-122.

Mata, J. and Machado, J. (1996), Firm start-up size: a conditional quantile approach, European Economic Review, Vol. 40, 1305-1323.

Mata, J. and Portugal, P. (1994), Life Duration of New Firms, The Journal of Industrial Economics, Vol. 42, no. 3, 227-245. 
Mata, J., Portugal, P. and Guimarães, P. (1995), The survival of new plants: Start-up conditions and post-entry evolution, International Journal of Industrial Organization, no.13, 459-481.

OECD (2008) Measuring Entrepreneurship: A digest of indicators.

Sarmento, E. and Nunes, A. (2009), Getting smaller: size dynamics of employer enterprises in Portugal, Cadernos Sociedade e Trabalho, Ministério do Trabalho e da Solidariedade Social (forthcoming).

Scarpetta, S., Hemmings, P., Tressel, T. and Woo, J. (2002), The role of policy and institutions for productivity and firm dynamics, OECD Economics Department Working Papers, no. 329.

Wagner, J. (1994), The Post-Entry Performance of new Small Firms in German Manufacturing Industries, The Journal of Industrial Economics XLII., 12 5-131. 